\title{
Culture and Role of Woman in Terrorism in Indonesia. Case Studies: Suicide Bombings in Surabaya and Sibolga
}

\author{
Muhaimin Zulhair Achsin
}

\begin{abstract}
Terrorism is a recognized global phenomenon particularly in the 21st century. Its landscape is highly determined by the actors' changing and shifting nature as well as the pattern of the main battle field in Middle East and Afghanistan. As the most populous Muslim country in the world, Indonesia has experienced terrorist attacks especially since 2000 where multiple threats of bombing in several areas of the country had surfaced as the consequences of global terrorism's wide spread networks and ideological influences. However, the two most recent suicide bombings in Surabaya - East Java on May 13, 2018 and Sibolga - North Sumatera on March 13, 2019 strongly indicate a new pattern of woman's role in terrorism in Indonesia, shifting from passive to active. Utilizing these case studies and the technique of interpretative research, this paper aims to describe woman's role in terrorist suicide bombing action, particularly in the context of Indonesia's patriarchal culture. The finding shows a different role of woman in terrorism according to the differences of the various cultures. Therefore, this research fills the void of terrorism research particularly in Indonesia.
\end{abstract}

Index Terms: culture, Indonesia, terrorism, woman

\section{INTRODUCTION}

Terrorism has become a world buzzword particularly after 9/11 attacks both of spoken and written. In the written world, for example, if we write the "terrorism" on the search engine of Taylor and Francis journal, it appears more than 95.000 articles and counting. Many writers have explained terrorism through particular angles such as economic, psychological, social, cultural, security, defense, political, networks, terrorist point of view so on and so forth. Therefore, the question is still anything left to be researched? The answer is strongly yes, since terrorism has no single unified concept or theory that could explain the many cases with a single satisfying concept, theory or explanation. Different cases, geographies, contexts, cultural settings, economic, social, and political condition and so on resulted different explanation.

This paper begins with the new dynamics of terrorism in Indonesia particularly the role of woman. Here, I use single noun of woman to describe every single woman who participate in terrorism has own characteristics. When the final decision making process of suicide bombings taken place, it was almost in the field of personal and nuclear family decision. Therefore, the use of word "woman" is not related to the explanation of numbers. This research based on the two case studies namely Surabaya suicide bombings

Revised Manuscript Received on April 19, 2019.

Muhaimin Zulhair Achsin, International Relations, Universitas Brawijaya, Malang, Indonesia. in East Java on May 2018 and Sibolga suicide bombing in North Sumatera on March 2019.

\section{A. Surabaya Suicide Bombings}

Sunday, May 132018 at 6.30 a.m., a considerably early time for Indonesians to start their activities, two boys named Yusuf (aged 18, a high school student) and Firman (aged 16, a middle school student) had said their farewell to their parents before then proceeding to ride together on a motorcycle with a bomb on the pillion passenger's lap. They entered the parking are of Santa Maria Tak Bercela Church and exploded themselves during a mass service. The explosion killed seven people (two suspects and five civilians).

Right at 7:15 a.m. of the same day a woman named Puji Kuswati (aged 43), unmistakably mother of Yusuf and Firman, forcefully entered The Indonesian Christian Church (GKI)'s terrace in st. Diponegoro. Puji Kuswati had not come alone, bringing along her two daughters named Fadhila Sari (aged 12) and Famela Rizqita (aged 9, an elementary school student). Puji Kuswati held her daughters' hands and blasted themselves in the entrance door of the church. Four people died in this suicide bombing, in which three of them are suspects and the other one being a security guard.

Later at 7:53 a.m. Dita Oepriarto (aged 48), husband of Puji and father of Yusuf, Firman, Fadhila, and Famela, broke through Pentakosta Church's terrace using a car and blasted himself. Seven people were killed in the explosion. Prior to the event, Dita had first escorted his wife and children to GKI in St. Diponegoro before then resuming his own journey to Pentakosta Church [1]. Prior to their suicide bombing actions, this family had finished their dawn prayer together, had time to hug and cry together after the dawn prayer [2]

Entering the 21 st century, a year prior to the 9/11 tragedy in the United States, Indonesia was first to experience the effect of terrorism. To prove, there are areas in Indonesia that were affected by terrorist activities which started from a simultaneous suicide bombing actions in eight different places on Christmas eve of 2000.

After this tragedy, bombings have occurred nonstop, for example in 2002 a bombing happened in Legian Bali that caused 200 people as casualties. Bombings kept on occurring even this year, however the pattern of the bombers have showed an anomaly with the event in 
Surabaya due to the involvement of kinship-family cell and woman as well as children, actively.

Terrorism has gone through a cell transformation from what used to be organized in an active cell into a family cell, but there is also a change in affiliation. Bombings in the early 2000s were heavily affiliated with Al-Qaeda through Jamaah Islamiyah, meanwhile after the emergence of ISIS as a big organization in the battle field of Middle East, there has been an emergence of a new organization affiliation in Indonesia through Jamaah Anshaarut Daulah (JAD). Bombers in Surabaya were a cell from JAD. In general, terrorist organizations in Indonesia are influenced by two big organizations namely Al-Qaeda and ISIS.

\section{B. Sibolga Suicide Bombing}

Because Different from the bombings in Surabaya - East Java, the suicide bombing in Sibolga - North Sumatera on March 13, 2019 did not target a church, but instead was a conscious decision by an individual person when surrounded by police officers. Solimah, the wife of a suspected terrorist named Abu Hamzah, decided to explode herself and her child (aged 2) when police officers had asked her to surrender. Prior to the suicide bombing action, negotiations were conducted for over five hours which involved Solimah's husband, Abu Hamzah, with the hope of persuading her to come out of the house.

Abu Hamzah's persuasion was not successful. Solimah was fixated on ending her life, disobeying her husband. This becomes an anomaly for terrorism phenomena in Indonesia. Family patronage culture has been a strong force previously, in which the husband's order towards his wife was dominant, but the wife who used to play a passive role had changed into a decision maker that was active in taking her own decision.

Therefore, looking at these two case studies, the writer proposes a question: how is woman's role in terrorist suicide culture in Indonesia? Simply, the writer sees a change and shift in the role that is played by woman within the patriarchal culture in Indonesia. The shift in woman's role is influenced by a particular culture.

\section{LITERATURE REVIEW}

There have been several literary works that explain woman's role in terrorism. Ortbals \& Poloni-Staudinger discuss woman changing the politics of terrorism. Sana'a Mehaydali a Lebanese and PPS (secular pro-Syrian Lebanese organization) operative, was the first modern woman suicide bomber. In 1985, at 17 years old, she blew herself up near vehicles carrying Israeli soldiers in Lebanon. According to Ortbals \& Poloni-Staudinger, woman is controlled by male-dominated terrorist groups as a tactic to attack. Woman is perceived to be more efficient because they are not attributed to violent tendencies [3]. Ortbals \& Poloni-Staudinger still consider woman as passive object.

Laura Sjoberg explains several situations in which woman is seen as active or passive. Active woman has a clear vision affiliated with political liberation group. Meanwhile, passive woman is usually recruited by terrorist organization such as Al-Qaeda [4].

Gonzalez-Perez explains that woman's contribution bombing action, particularly in the context of society's

in terrorist activities are rising due to affiliations with rebel groups. Perez says that the inclination of terrorist acts done by woman happen because they seek higher positions within the hierarchy of the domestic terrorist group [5]. Several other works also discuss woman and terrorism, which are women in modern terrorism [6] and female suicide bombings in gender perspective [7], meanwhile Barton explains about Jemaah Islamiyah in Indonesia [8].

Ramakhrishna instead discusses terrorism as a matter of human nature. Terrorist acts are manifestations of evil that exists in human's mind naturally. It is explained as if the actors of terrorism have always been evil in nature and base their actions in the name of evil [9].

Nava Nuraniyah gives an account that woman terrorist in Indonesia still asks for approval from men to do suicide bombings. Nuraniyah takes the example of two women bomber suspects whose actions were prevented by the police, named Ika Puspitasari (aged 36), a labor who has worked in Malaysia and Hong Kong, and Dian Yulia Novi, an ex-migrant worker that worked in Taiwan [10].

\section{DISCUSSION}

This paper uses the interpretive qualitative method through the two case studies and interpret it based on cultural condition in Indonesia, particularly where the case studies were taken places. In this context, culture is defined, according to Raymond Williams, as particular way of life (people, a period or a group). However, in cultural studies itself analyze the ideology. Ideology can refer to a systematic body of ideas articulated by a particular group [11].

The dominant particular way of life that is present in Indonesia as a country with the largest Muslim population in the world is the nuance of Islam, however several areas where religions other than Islam are the majority such Province of North Sulawesi (Christianity) or Bali (Hinduism) show that the religious values of those religious majorities have become the foundation and way of life for the local society. Despite of whichever religion, it can be said that in general Indonesian society hold the patriarchal system.

However, patriarchy in Indonesia is not as strict as in Arab's culture. Woman in Indonesia, in many cases, has better access than woman in Arab for things such as education, economy, equality, politics and others. Beside religion, the nuance of ethnicity also influences the society's condition in Indonesia. Indonesia has hundreds of ethnics with Javanese ethnic as the biggest population, mounting up to $40 \%$ of total population.

In the case of the bombers in Surabaya, Puji Kuswati was a Javanese woman born in Banyuwangi - East Java Province. Economically, Puji Kuswati was a middle upper class as she was the daughter of a businessman in Banyuwangi. However, her relationship with her parents was not in harmony after she had married Dita. Puji's parents still bought them three cars. Two of the cars were resold and the last car was used to carry out the suicide 
bombing mission. Seen from Puji's case, economic analysis fails to explain the phenomenon because she was not a person who was desperate in the state of poverty or had any economic problem to deal with.

From the perspective of Javanese traditional culture, a woman holds such a domestic role including macak (dress up/attract), manak (raise and educate children), and masak (cook). Traditionally, woman is positioned to have roles inside of the household with a soft image, meanwhile men are positioned to have roles outside. In this culture, it is not surprising to see a mother having a close relationship with her children, biologically and psychologically. A mother, as the first educator of their children, is present before the children are to see start any formal education.

The nuance of Islam obliges a wife to be obedient towards her husband as the one to guide the family. In this case, it can be interpreted that Puji's obedience towards her husband Dita to carry out suicide bombing mission is a form of obedience that is justified by culture and religion. Meanwhile, the offering and strengthening of the children to do the same thing is a role that is played by the mother. Here the role of woman in family becomes more important and strategic. It serves the double functions, to strengthen the husband's will and embrace the children.

JAD's ideology that follows ISIS states that a state which is not based on Islam laws is an infidel state and those who run it are thogut. This ideology has crystallized and created a hostile situation that is very tense between Jemaah ideologists and state apparatus as well as the society. This ideology makes the actors become braver because there is a belief and justification to use suicide bombing mission as a way to fight against any supporter of the infidel state.

Clash between terrorism ideology and Javanese culture happen in this point. Javanese culture emphasizes harmonized peace with values of patience, acceptance, and wisdom. Meanwhile, the terrorism ideology perceives even moderate Muslim as people who have no knowledge regarding the religion itself and demanding to the more extreme actions.

In this Puji's case, cultural values are defeated by terrorism ideology. Culture that is involved in religious affairs, continuously thicken terrorism ideology that believes in the many flaws of society. Therefore, death is perceived as a way out that is perfect from a life that is filled with uncertainty and sin. Preparing to die becomes more real than preparing for life, death becomes more real than life itself. A change in the way of thinking happened regarding the particular way of life.

In the case of lone-wolf bomber Solimah in Sibolga, the woman was from Padang Sidempuan, a city in North Sumatra. This area is inhabited mostly by the Mandailing and Batak Toba sub-ethnics. These two sub-ethnics are the sub-ethnics from a popular Batak tribe that is known for its assertiveness and high self-pride.

In this culture, it can be interpreted that Solimah's action of exploding herself and her child when surrounded by the police was a form of assertiveness and protection towards her own pride, hence the reason why she made it her decision to choose suicide. If she had surrendered, it would have showed her weakness as well as making her the talk of her whole family which would be degrading for her pride.
In this case, the nuance of culture is stronger than the nuance of religion that states for a wife to be obedient towards her husband. The proof is that Abu Hamzah, husband of Solimah, has failed to persuade her because Solimah disobeyed him as a wife. Even though the Chief of the Indonesian Police - Police-General Tito Karnavian [12] states that Solimah believes suicide is a shortcut to heaven. Here Tito neglected the influence of cultural element and made the ideology as the one and only factor.

\section{CONCLUSION}

From these two cases, woman's role in suicide bombing missions are attributed to the influence of cultural elements. In Puji's case, Javanese culture was defeated by terrorism ideology and therefore her obedience towards Dita, her husband, had a real justification. Meanwhile Solimah's woman role became very active and independent in making her own decision. The nuance of culture becomes very much present rather than the ideological doctrine itself which disobeyed her husband's order and rejected the patriarchal custom. From these two cases, a change in woman's role from passive to active can be seen and is influenced by, one of them being, the cultural element. Moghaddam [13] posits that terrorists are made, they are not born, they arise from societal conditions.

\section{REFERENCES}

1. Damarjati D. Terorisme Terlaknat 2018: Bom Sekeluarga Mengguncang Surabaya. 2018.

2. Liputan6. 3 Ritual Dilakukan Pelaku Bom Gereja Surabaya Sebelum Meledakkan Diri. 2018.

3. Ortbals CDa, Poloni-Staudinger La. Gender and political violence : women changing the politics of terrorism.

4. Sjoberg L, Gentry CE. Women, gender, and terrorism. Athens, Ga.: University of Georgia Press; 2011.

5. Gonzalez-Perez M. Women and terrorism : female activity in domestic and international terror groups.

6. Davis Ja. Women in modern terrorism : from liberation wars to global Jihad and the Islamic State.

7. Narozhna Ta, Knight WAa. Female suicide bombings : a critical gender approach.

8. Barton G. Jemaah Islamiyah : radical Islamism in Indonesia. Singapore: Ridge Books; 2005.

9. Ramakrishna Ka. Islamist Terrorism and Militancy in Indonesia : The Power of the Manichean Mindset. 2015. ed.

10. Nuraniyah N. Not Just Brainwashed: Understanding the Radicalization of Indonesian Female Supporters of the Islamic State. Terrorism and Political Violence. 2018;30(6):890-910.

11. Storey Ja. Cultural theory and popular culture : an introduction. Eighth edition. ed.

12. CNN. Tito Sebut Istri Abu Hamzah Percaya Bunuh Dir Cepat ke Surga. 2019.

13. Moghaddam FM. From the terrorists' point of view what they experience and why they come to destroy. Westport, Conn. ; London: Praeger Security International ;; 2006. 
International Conference on Recents Advancements in Engineering and Technology (ICRAET-18) |15th and 16th March 2019|Siddhartha Institute of Technology \& Sciences, Telangana, India.

\section{AUTHOR PROFILE}

Muhaimin Zulhair Achsin, M.A International Relations, Universitas Gadjah Mada - Indonesia. Lecturer in International Relations department, faculty of social and political sciences - Universitas Brawijaya, Malang, Indonesia. 